\title{
Dynamics of innovation and taxation in 8 EU ex- communist countries
}

\author{
Victor Marian Dumitrache ${ }^{1, *}$, Cristina Dima $^{2}$, Victor Adrian Troaca ${ }^{1}$, and Valentin Pauna ${ }^{1}$ \\ ${ }^{1}$ Bucharest University of Economic Studies, PhD student, Piata Romana nr. 6, 010374, Bucharest, \\ Romania \\ ${ }^{1}$ Bucharest University of Economic Studies, Assistant Professor PhD, Piata Romana nr. 6, 010374, \\ Bucharest, Romania
}

\begin{abstract}
Research background: Even if they have a similar background, the excommunist countries in Europe have started since the '90s to differentiate socially and economically one from another. Nowadays, the differences between them are significant in many aspects of the socio-economic environment, including innovation. Measurements done by Cornell University, INSEAD, and WIPO through the Global Innovation Index and some researchers compared the achievements from the last 30 years of the ex-communist countries in terms of innovation. Although innovation may be under the influence of multiple factors, some authors suggest that taxation has a major role.

Purpose of the article: The purpose of the article is identifying a potential link between the dynamics of innovation and the dynamics of taxation in 8 ex-communist EU countries in the context of globalization, and to describe the way the globalization and taxation together fostered or suppressed the innovation.

Methods: We will do a comparative analysis, comparing the taxation and the innovation input and output indicators - regulatory environment, education, general infrastructure, credit, investment, knowledge workers, knowledge creation, knowledge impact, online creativity, intangible assets. Findings \& Value added: This paper may add value to the economic and taxation policies in the ex-communist countries by identifying the policies that proved their effectiveness in increasing innovation rates, policies that can be adapted and then adopted by the ex-communist countries that are less innovative.
\end{abstract}

Keywords: taxation; innovation; globalization; ex-communist countries in Europe

JEL Classification: $O 30 ; F 63$

\footnotetext{
* Corresponding author: victor.dumitrache@gmail.com
} 


\section{Introduction}

Taxation influences directly or indirectly every aspect of production and distribution (James, 2001), including the development of new products and production techniques and technologies (Bodislav et al., 2020).

There is a strong body of evidence showing that physical accumulation of capital and labor supply, as key factors in economic development (Piketty et al, 2019), are important channels through which taxation policy impacts the economy and influences its growth (Bodislav et al., 2020). Tax rates on capital gains, dividends, labor income and corporate income have significant effects on innovative investments and thereby on aggregate labor productivity and TFP growth (Ferraro et al., 2020).

Changes in the taxation policy may influence the economy growth depending on the economic growth model of the country. Kates and Milionis (2019) showed that only countries with an innovation-based growth model benefit from a corporate tax rate reduction, by allowing companies that are already innovation orientated to accumulate more capital and innovate even more (Ohrn, 2018).

Many of the mechanisms of transmission of tax policy into economic growth are still to be uncovered and there is a high demand for both qualitative and quantitative research (Jianu et al., 2019).

In 1999, Schulze and Ursprung summarized the academic debate on taxation policy and globalization to two effects: the efficiency effect and the compensation effect. The efficiency effect is the one which makes the countries to lower the tax rates to stay competitive in the context of market economy, especially within the EU borders (Jha and Gozgor, 2019), fostered by the free move of goods and capitals makes. This effect lowers the governments' ability to provide public goods (Profiroiu et al., 2020). The compensation effect refers to the increasing demand of social aid due to the high rates of migration fostered by globalization (Bran et al., 2020).

\section{Purpose of the article}

The purpose of the article is to identify a potential link between the dynamics of innovation and the dynamics of taxation in 8 ex-communist EU countries in the context of globalization, and to describe the way the globalization and taxation together fostered or suppressed the innovation.

We considered that is more relevant to test the existence of this link between taxation and innovation on these 8 countries because they share similar background before the ' 90 s, they entered capitalism and democracy almost in the same period and, moreover, they are all have been part of the EU for at least 8 years. Based on Global Innovation Index (GII), in 2019, out of the 8 countries, the lowest rated was Romania (25th) with a GII score of 36.8 and the highest rated among the 8 was Czech Republic (26th) with a GII score of 49.4 and as shown in table 1 . 
Table 1. Ex-communist EU countries sorted by GII rank.

\begin{tabular}{|c|c|c|}
\hline Country & GII Rank & GII Score \\
\hline Czech Republic & 26 & 49.4 \\
\hline Slovenia & 31 & 45.3 \\
\hline Hungary & 33 & 44.5 \\
\hline Slovakia & 37 & 42 \\
\hline Poland & 39 & 41.3 \\
\hline Bulgaria & 40 & 40.3 \\
\hline Croatia & 44 & 37.8 \\
\hline Romania & 50 & 36.8 \\
\hline
\end{tabular}

Source: Bran (2020)

In figure 1 we can see the distribution of tax revenues according to type of tax, as percentage of total taxes. We can observe that, out of the 8 countries, Croatia (50.95\%) has the highest share of consumption taxes in total taxes and Bulgaria (47.2\%) has the lowest share, far above the EU-27 average (27.8\%). According to Gunter et al. (2019), consumption tax cuts would strongly stimulate economic activity in these countries.

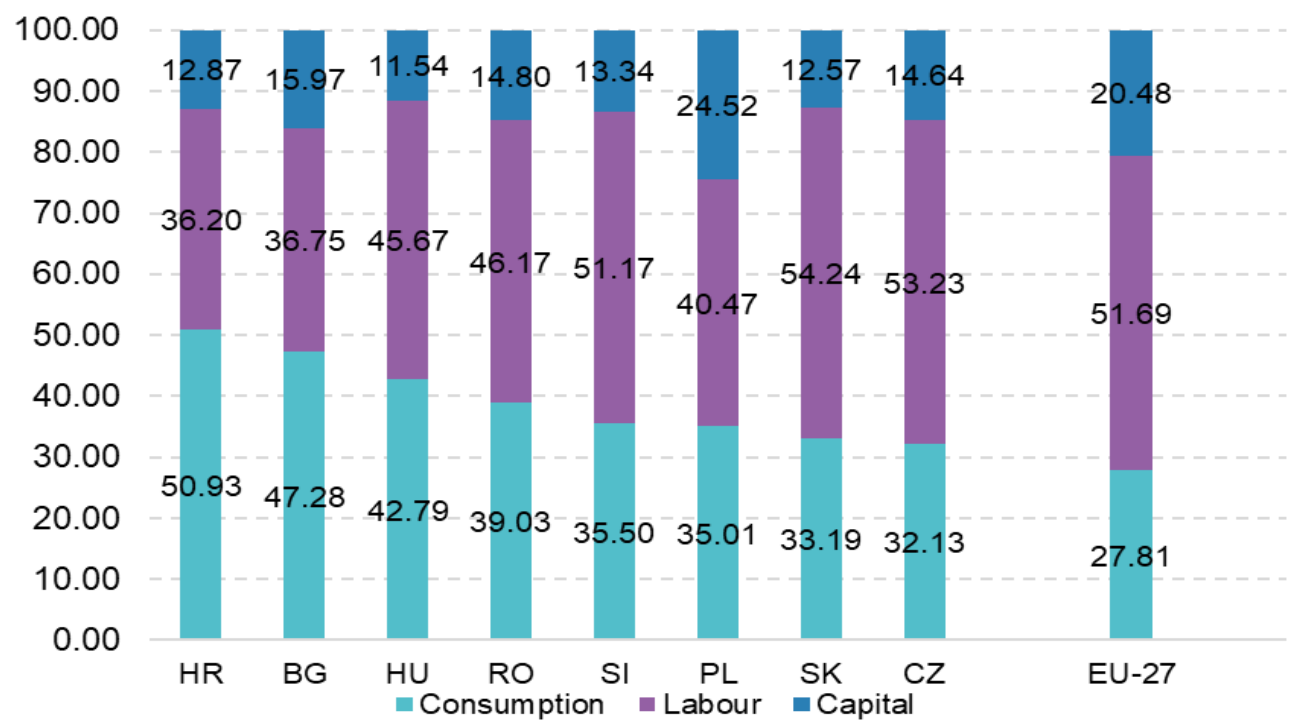

Figure 1. Distribution of tax revenues according to type of tax base $2019, \%$ of total taxes.

Source: European Commission, DG Taxation and Customs Union

Also, we can observe that, by the criterion of consumption taxes share in total taxes, all 8 ex-communist EU countries are above EU-27 average consumption tax rates, indicating policies that support the development of private sector, with lower labor and capital taxes. 


\section{Methods}

Following the purpose of this paper, we used Pearson correlation test together with the graphic representation of the relation between the Global Innovation Index (GII) Score and few indicators that reflect the results of the fiscal policy: 1) share of taxes on consumption in total tax revenues, 2) share of taxes on labor in total tax revenues and 3) share of taxes on capital in total taxes revenue.

For all of these fiscal indicators we used data from 2019. The data sources are: European Commission, DG Taxation and Customs Union and Eurostat.

The GII score source is the Global Innovation Index (GII) raw data that can be found in the Global Innovation Index 2019, 12th edition. The relevant data were aggregated by the authors in a spreadsheet where it was processed and where charts were generated.

The GII is based on two sub-indices: Innovation Input Sub-Index built on 5 key pillars and the Innovation Output Sub-Index built on 2 key pillars.

Five input pillars capture elements of the national economy that enable innovative activities: (1) Institutions, (2) Human capital and research, (3) Infrastructure, (4) Market sophistication, and (5) Business sophistication. Two output pillars capture actual evidence of innovation outputs: (6) Knowledge and technology outputs and (7) Creative outputs.

Each pillar is divided into 3 sub-pillars and each sub-pillar is composed of individual indicators (80 in total in 2019). Sub-pillar scores are calculated as the weighted average of individual indicators; pillar scores are calculated as the weighted average of sub-pillar scores.

\section{Results and Discussion}

\subsection{Findings}

Figure 2 shows the relation between the GII score (data from table 1) and the share of consumption taxes in total tax revenues in the $8 \mathrm{EU}$ ex-communist countries.

From the cart we can observe that there is a negative correlation between these two variables. The highest is the Global Innovation Index Score, the lowest is the share of consumption taxes in total tax revenues. We can say that the more innovative is an economy, the less the government relies on consumption taxes, because an innovative and highly digitalized economy can generate more tax revenues from other sources (exp.: labor taxes or direct taxes).

However, the correlation is moderate with a coefficient of correlation of -.57 and a coefficient of determination is 0.33 .

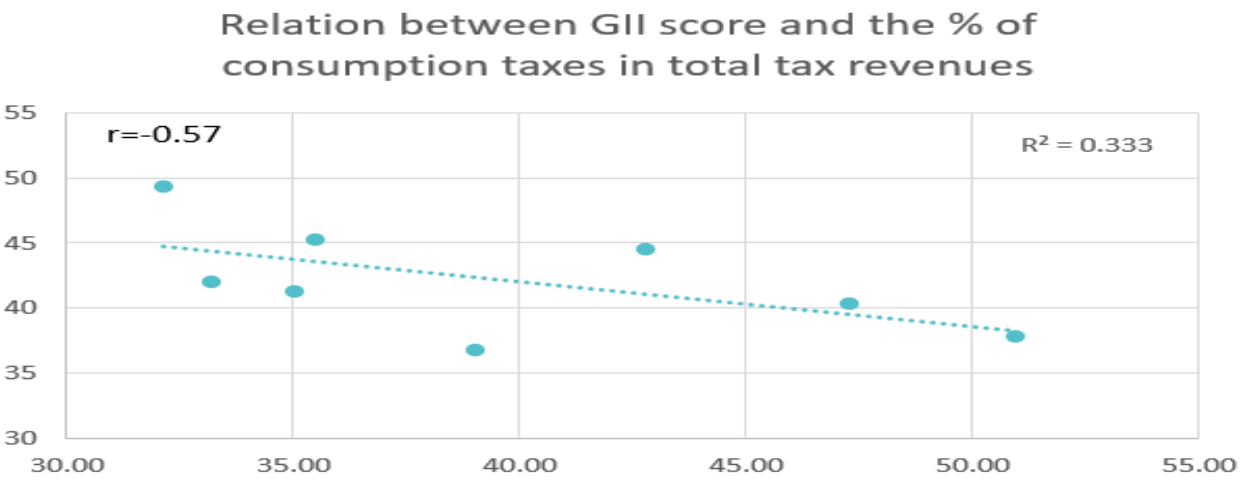

Figure 2. Relation between GII score and the \% of consumption taxes in total tax revenues.

Source: the authors 
Figure 3 shows the relation between the GII score (data from table 1) and the share of labor taxes in total tax revenues in the $8 \mathrm{EU}$ ex-communist countries.

From the chart we can observe that there is a positive correlation between these two variables. The highest is the Global Innovation Index Score, the highest is the share of labor taxes in total tax revenues. This finding strengthens the observation made above, that the more innovative is an economy, the labor is higher qualified, receiving a higher salary also and having higher expectation regarding social services (Radulescu et al., 2021). This comes with high wages and with high revenues from the social taxes and also with high quality public goods (Radulescu et al., 2020).

This correlation also shows that EU has a highly competitive labor market due to its higher education capabilities, training the top professionals worldwide (Dumitrache et al., 2020).

The correlation is moderate with a coefficient of correlation of 0.63 and a coefficient of determination of 0.39

\section{Relation between GII score and the \% of labour taxes in total tax revenues}

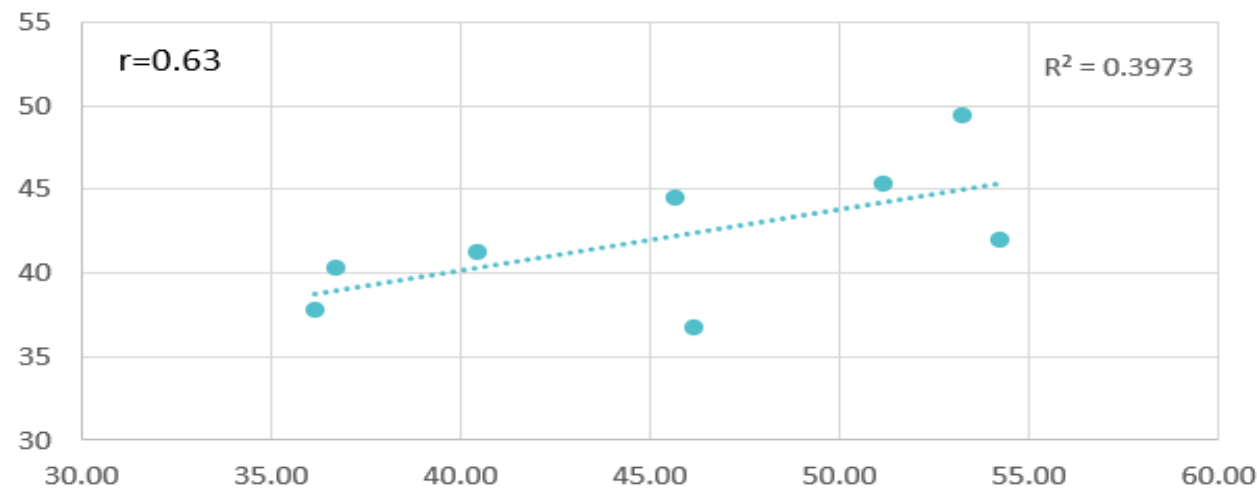

Figure 3. Relation between GII score and the \% of labor taxes in total tax revenues

Source: the authors

Figure 4 shows the relation between the GII score (data from table 1) and the share of capital taxes in total tax revenues in the $8 \mathrm{EU}$ ex-communist countries.

From the chart we can observe that there is no correlation between Global Innovation Index Score and the share of capital taxes in total taxes revenue. The coefficient of correlation is 0.12 and the coefficient of determination is 0.01 . It means that any variation in one of these two variables will not be related in any way with variations on the other one. This finding may suggest that EU ex-communist countries keep a low level of capital taxes to stay attractive for investors and entrepreneurs. 


\section{Relation between GII score and the \% of capital taxes in total tax revenues}

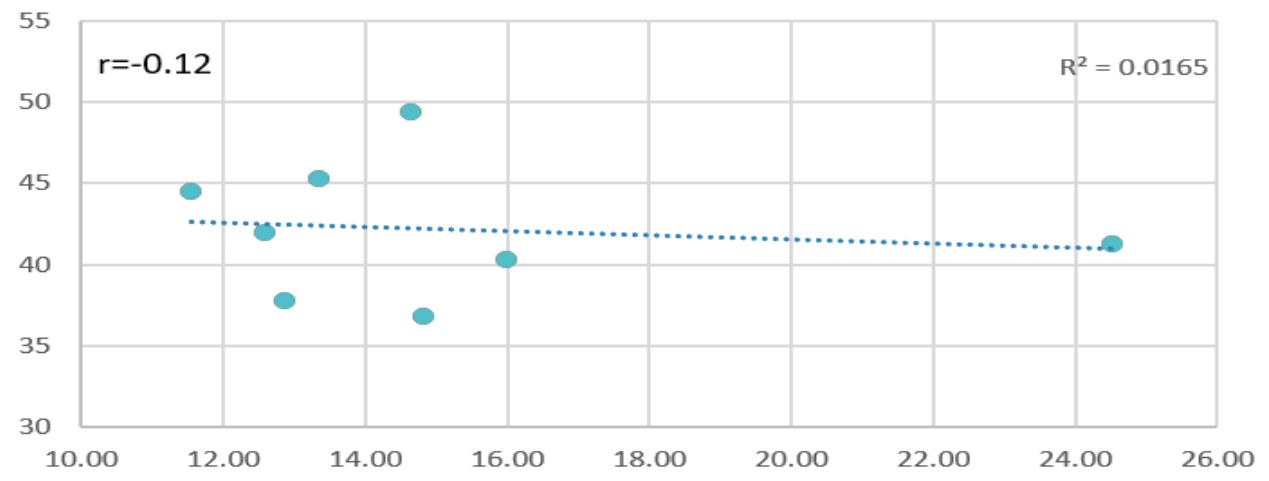

Figure 4. Relation between GII score and the \% of capital taxes in total tax revenues.

Source: the authors

\section{Conclusion}

In this article we aimed to identify a potential link between the dynamics of innovation and the dynamics of taxation in 8 ex-communist EU countries in the context of globalization, and to describe the way the globalization and taxation together fostered or suppressed the innovation.

From the analysis we observed that there is a moderate correlation between the Global Innovation Index Score and the share of labor taxes in total tax revenues. This finding highlights the competitiveness of EU labor market, the high level of salaries of the highly qualified labor and the way all of these get higher as the economy becomes more innovative (Burlacu et al., 2021).

The analysis also shows that, maybe in the context of globalization, regardless their level of innovation reflected in the Global Innovation Index Score, the 8 countries have similar shares of capital taxes in total tax revenue. This finding may reflect their strategy to stay attractive for entrepreneurs and investor by practicing low levels of capital taxes.

Further research may take into consideration specific pillars of the Global Innovation Index as Market sophistication, Business sophistication and Knowledge and technology outputs. There could be a more significant correlation between these pillars and the level of taxation. Also, regarding taxation, other tax classification and other tax indicators can be considered, like the share of direct and indirect taxes in total tax revenues.

\section{References}

1. Bodislav, D. A., Buzoianu, O. A. C., Burlacu, S., \& Rădulescu, C. V. (2020). Analysis of companies in Romania from the perspective of risk perception and the management needs thereof. Economic Convergence in European Union, 341.

2. Bodislav, D. A., Radulescu, C. V., Bran, F., \& Burlacu, S., (2020). public policy in the areas of environment and energy. 6th BASIQ International Conference on New Trends in Sustainable Business and Consumption. Messina, Italy, 4-6 June 2020, (pp. 228-235). 
3. Bran, F., Rădulescu, C. V., Bodislav, D. A., \& Burlacu, S. (2020). Environmental risks in the context of globalization. Economic Convergence in European Union, 350.

4. Burlacu, S., Diaconu, A., Balu, E. P., \& Gole, I. (2021). The economic and social effects of unemployment in Romania. Revista de Management Comparat International, 22(1), 21-27.

5. Ferraro, D., Ghazi, S., \& Peretto, P. F. (2020). Implications of tax policy for innovation and aggregate productivity growth. European Economic Review, 130.

6. Jha, P., \& Gozgor, G. (2019). Globalization and taxation: Theory and evidence. European Journal of Political Economy, 59, 296-315.

7. Jianu, I., Dobre, I., Bodislav, D. A., Radulescu, C. V., \& Burlacu, S. (2019). The implications of institutional specificities on the income inequalities drivers in European Union. Economic Computation and Economic Cybernetics Studies and Research, 53(2), 59-76.

8. Kate, F., \& Milionis, P. (2019). Is capital taxation always harmful for economic growth?, International Tax and Public Finance, 26(4), 758-805.

9. Ohrn, E. (2018). The effect of corporate taxation on investment and financial policy: Evidence from the DPAD. American Economic Journal: Economic Policy, 10(2), 272301.

10. Piketty, T., Li Y., \& Zucman, G. (2019). Capital accumulation, private property, and rising inequality in China, 1978-2015. American Economic Review, 109(7), 2469-2496.

11. Profiroiu, M. C., Radulescu, C. V., Burlacu, S., \& Guţu, C. (2020). Changes and trends in the development of the world economy. In Competitivitatea şi inovarea în economia cunoaşterii, (pp. 324-330).

12. Rădulescu, C. V., Bodislav, D. A., Burlacu, S., Bran, F., \& Karimova, L. (2020). Econometric model for forecasting oil production in OECD member states. In E3S Web of Conferences, 159, 02005.

13. Radulescu, C. V., Ladaru, G.-R., Burlacu, S., Constantin, F., Ioanăș, C., \& Petre, I. L. (2021). Impact of the COVID-19 Pandemic on the Romanian labor market. Sustainability, 13, 271.

14. Schulze, H. W. Ursprung globalisation of the economy and the nation state. World Economy, 22(3), 295-352.

15. Gunter, S., Riera-Crichton, D., Vegh C., \& Vuletin G. (2019). Non-linear effects of tax changes on output: The role of the initial level of taxation. National Bureau of Economic Research.

16. Cornell University, INSEAD, and WIPO (2019), The Global Innovation Index 2019: Creating healthy lives - the future of medical innovation, Ithaca, Fontainebleau, and Geneva edition.

17. James, S. (2001), Taxation research as economic research, https://businessschool.exeter.ac.uk/documents/papers/management/2001/0107.pdf.

18. Bran, F., Niculescu, M. A., Dumitrache V. M., \& Gombos S. P. (2020). The dynamics of innovation in the ex-communist countries in Europe in the context of globalization. The 20th International Scientific Conference Globalization and its Socio-Economic Consequences 2020.

19. Dumitrache, V. M., Gombos, S. P., Bran, F., \& Balu, E. B. (2020). The dynamics of human capital accumulation in the ex-communist countries in Europe in the context of globalization, The 20th International Scientific Conference Globalization and its SocioEconomic Consequences 2020. 
20. Database of https://www.globalinnovationindex.org/analysis-economy.
Index

2019 , 